\title{
Role of Calcium Regulationg Hormones in the Pathogenesis of Senile Osteoporosis
}

\author{
HaJime ORIMO and Masataka SHIRAKI
}

Section of Endocrinology Tokyo Metropolitan

Geriatric Hospital, Itabashi, Tokyo

Osteoporosis characterized by the loss of bone mass is quite common in the old people.

Although aging of the bone has been considered as main causative factor in this morbid state, the role of other factors in the pathogenesis of this disease is still obscure.

Furthermore, it is still not clear whether it is possible to distinguish pathological osteoporosis from the physiological loss of bone mass with aging. The purpose of the present study is firstly to clarify the role of calcium regulating hormones and aging in the maintenance of bone mineral in the aged female and secondly to characterize the pathological osteoporosis and to distinguish pathological osteoporosis from physiological loss of bone mineral with aging in the females. Fig. 1 shows an effect of aging on radial mineral content in 381 Japanese. The presence of the fracture of the vertebrae or hip bone was checked by the $\mathrm{X}$ ray films and the radial mineral content was measured by photon absorption technique by Norland and Cameron. As shown in Fig. 1, radial mineral content tended to decre with advancing age in both sexes.

However, the rate of decrease in the radial mineral content after the age of 40 was greater in women than in men. Female

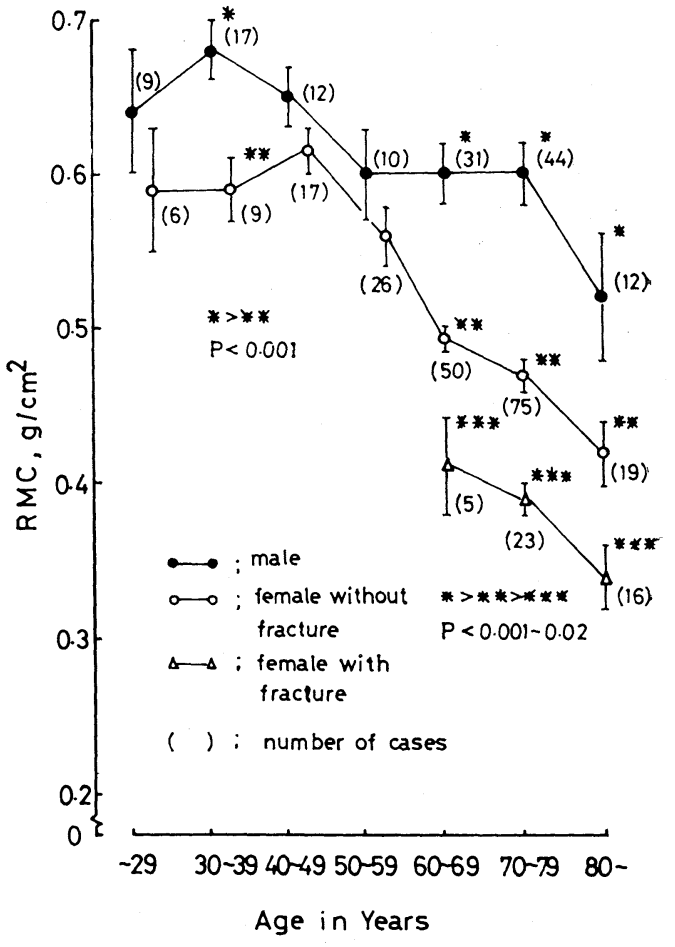

Fig. 1. Effect of aging on the radial mineral content. Greater radial mineral contents in the males than in the females. Sharp decrease in the mineral content after 50 in the females. Smaller mineral content in the females with fracture than in those without fractures. In this and in Fig. 2-6 vertical bar represents standard error of the mean. 
subjects with fractures had a significantly less radial mineral content than the age matched controls.

In an attempt to clarify the role of calcium regulating hormones in the maintenance of bone mineral in the aged female, we have subseqently studied the correlation between serum estradiol, testosterone, $25(\mathrm{OH}) \mathrm{D}_{3}, 1,25(\mathrm{OH})_{3} \mathrm{D}_{3}$ and parathyroid homone (PTH) with radial mineral content, respectively. Serum estradiol levels were measured by the radioimmunoassay developed by Murakami et al. and serum total testosterone levels were measured by the radioimmunoassay kit (Midorijuji Co.).

Serum $25(\mathrm{OH}) \mathrm{D}_{3}$ levels were measured by the competitive protein binding assay developed by Haddad et al. and serum $1,25(\mathrm{OH})_{2} \mathrm{D}_{3}$ levels were measured by the radioreceptor assay originally described by Eisman et al.

Serum PTH levels were measured by the radioimmunoassay using antiserum wellcome $211 / 41$ against $1-84$ bovine $\mathrm{PTH}$ as a standard. Table 1 summarizes the correlation between radial mineral content and various calcium regulating hormones in the aged female. Serum estradiol, testosterone, $25(\mathrm{OH}) \mathrm{D}_{3}$ and $1,25(\mathrm{OH})_{2} \mathrm{D}_{3}$ levels had a significant positive correlation with the radial mineral content respectively, while serum i PTH levels had a negative correlation with radial mineral content. Since it is possible that the loss of bone mineral in the aged female can be divided into two categories, physiological loss of bone mineral with aging and the pathological osteoporosis characterized by fractures, we have subsequently attempted to characterize the aged females with or without fractures.

Firstly, we have studied the age-related changes in the serum concentration of calcium regulating hormones in the aged females without fractures. As shown in Fig. 2, serum estradiol levels in the females fall rapidly after the age of 60 and stayed
Table 1.

Correlation Coefficient between Radial Mineral Content and Various Factors in the Aged Female

\begin{tabular}{|c||c|c|c|c|c|}
\hline & $\begin{array}{c}E_{2} \\
(\mathrm{pg} / \mathrm{ml})\end{array}$ & $\begin{array}{c}\text { Testosteron } \\
(\mathrm{ng} / \mathrm{ml})\end{array}$ & $\begin{array}{c}25-\mathrm{OH} \mathrm{D}_{3} \\
(\mathrm{ng} / \mathrm{ml})\end{array}$ & $\begin{array}{c}1.25(\mathrm{OH})_{2} \mathrm{D}_{3} \\
(\mathrm{pg} / \mathrm{ml})\end{array}$ & $\begin{array}{c}\mathrm{PTH} \\
(\mathrm{ng} / \mathrm{ml})\end{array}$ \\
\hline $\mathrm{N}$ & 46 & 39 & 53 & 22 & 41 \\
\hline \hline $\begin{array}{l}\mathrm{RMC} \\
\left(\mathrm{g} / \mathrm{cm}^{2}\right)\end{array}$ & $0.396^{*}$ & $0.433^{*}$ & $0.510^{*}$ & $0.620^{*}$ & $-0.468^{*}$ \\
\hline \\
$\begin{array}{c}* \\
\text { N P }<0.01 \\
\text { N Number of Cases }\end{array}$
\end{tabular}

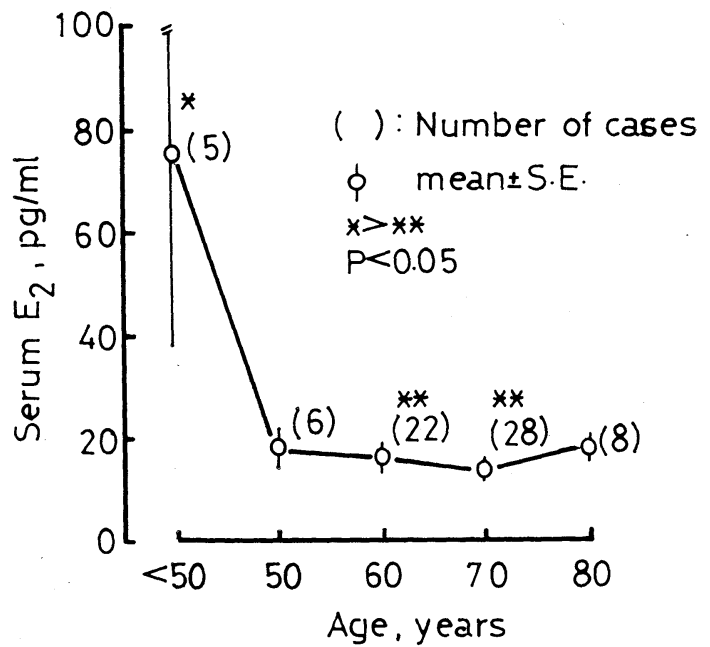

Fig. 2. effect of aging on serum estradiol levels in the female. Rappid fall of serum estrodiol after the age of 50 . Vertical bar represents standard error of the mean.

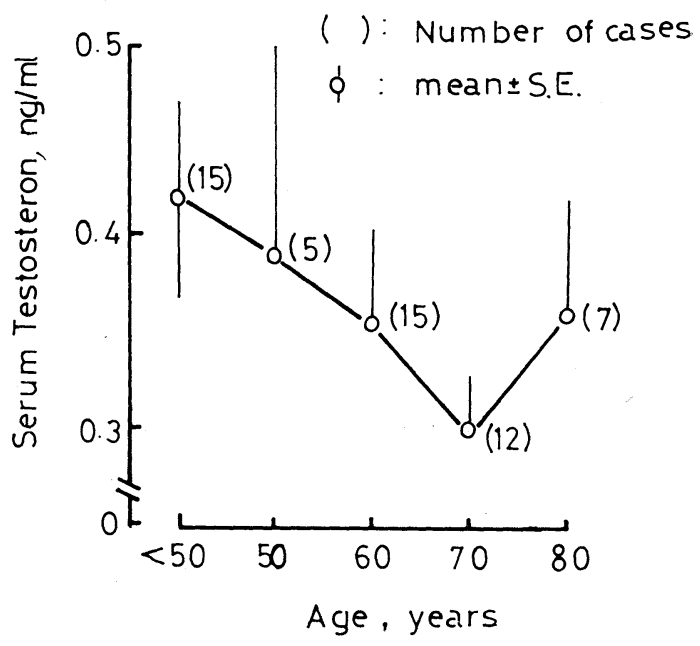

Fig. 3. Effect of aging on serum testosterone levels in the female. No significant changes in serum testosterone levels with age. 


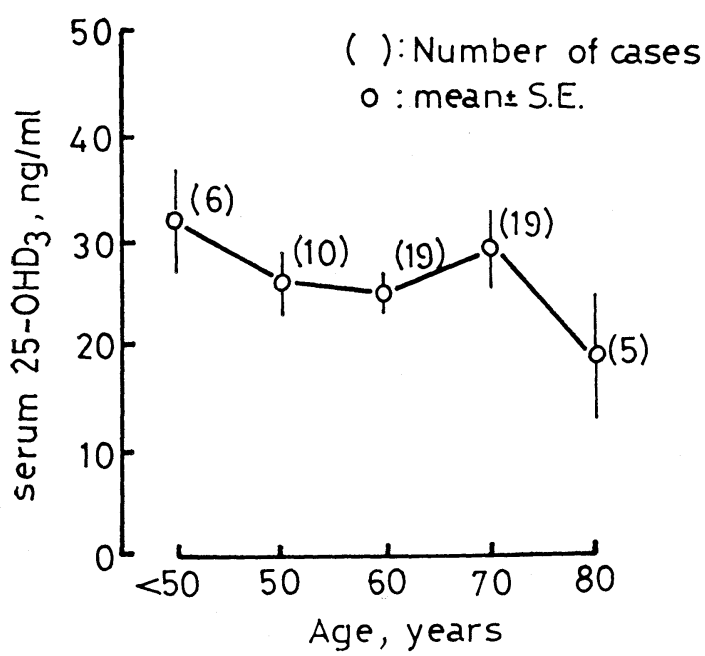

Fig. 4. Effect of aging on serum $25-\mathrm{OHD}_{3}$ levels in the female. No significant changes in serum 25 $\mathrm{OHD}_{3}$ with age.

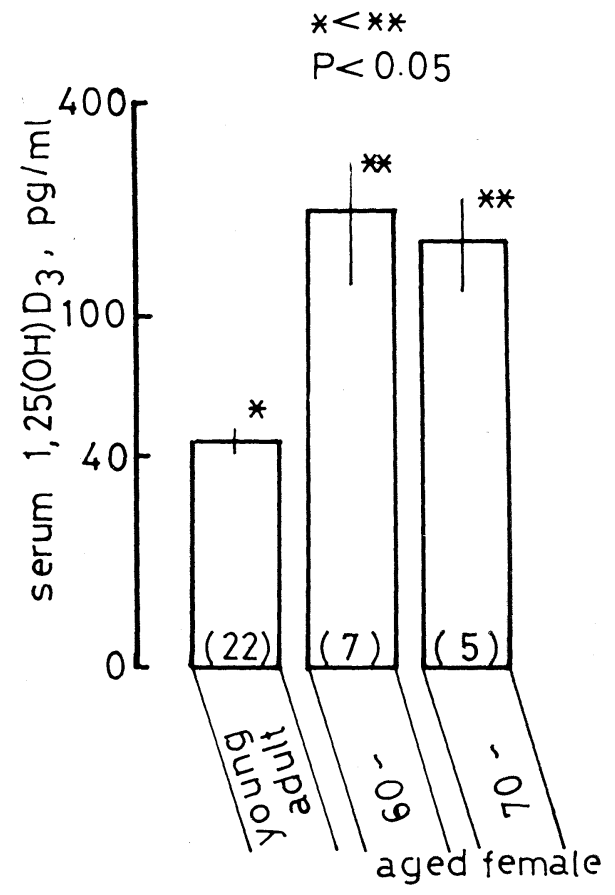

Fig. 5. Effect of aging on serum $1,25(\mathrm{OH})_{2} \mathrm{D}_{3}$ in the female. Higher serum $1,25(\mathrm{OH})_{2} \mathrm{D}_{3}$ levels in the aged females than in the young adult. low thereafter. Serum testosterone levels in the female tended to decrease with age, but the changes were not significantly different (Fig. 3). There was no significant change in serum $25(\mathrm{OH}) \mathrm{D}_{3}$ levels with aging. (Fig. 4) Serum $1,25(\mathrm{OH})_{2} \mathrm{D}_{3}$ levels in the aged females were significantly higher than that of the young adults. (Fig. 5).

As shown in Fig. 6, serum PTH levels in the famale significantly rised with advancing age.

In view of these facts, it is possible that the fall in the radial mineral content with age in the female were caused through the changes in the calcium regulating hormones, together with the effect of aging by itself.

Increase in serum PTH levels and decrease in serum estradiol levels with aging may contribute to the loss of bone mineral

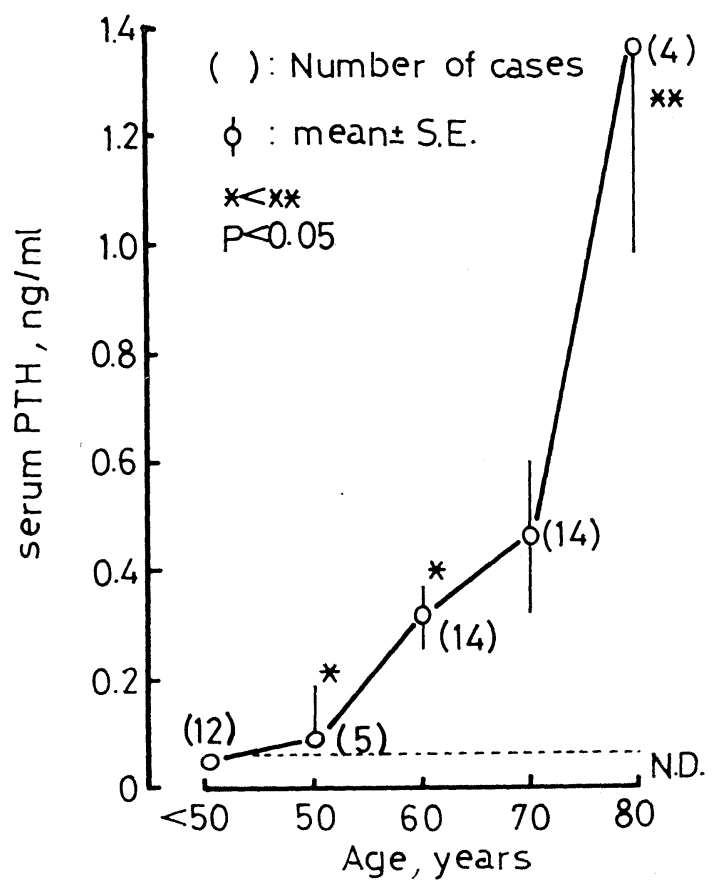

Fig. 6. Effect of aging on serum PTH levels in the female. Increase in serum PTH levels with age. 
with aging, together with the effect of aging by itself.

On the other hand, decrease in serum testosterone and $25(\mathrm{OH}) \mathrm{D}_{3}$ levels may accelerate the physiological loss of bone mineral, a part from the effect of aging by itself, since neither serum testosterone nor $25(\mathrm{OH}) \mathrm{D}_{3}$ changed with age. Subsequently in an attempt to characterize the pathological osteoporosis in the females, we have compared various parameters in the females with fractures (pathological osteoporosis) and the age matched controls. (females without fractures). In Fig. 7 are shown the age and the radial mineral content in the females with fractures and those in the females without fractures. It is of noteworthy that the radial mineral content in the females with fracture was significantly

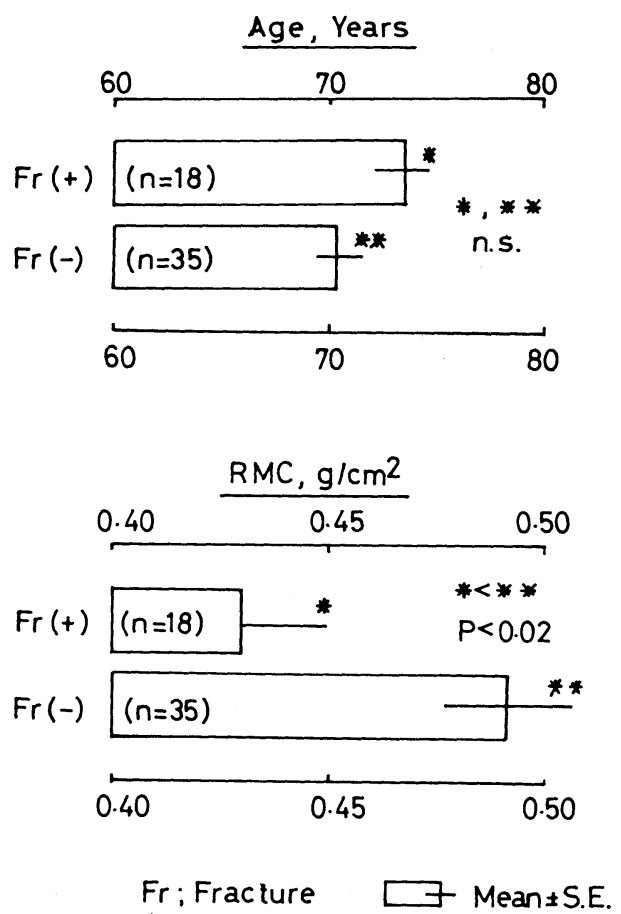

Fig. 7. Age and radial mineral content in the aged female with or without fractures. Smaller RMC in the females with fractures than in those without fractures. In this and in Fig. 8-11 horizontal bar represents standard error of the mean.

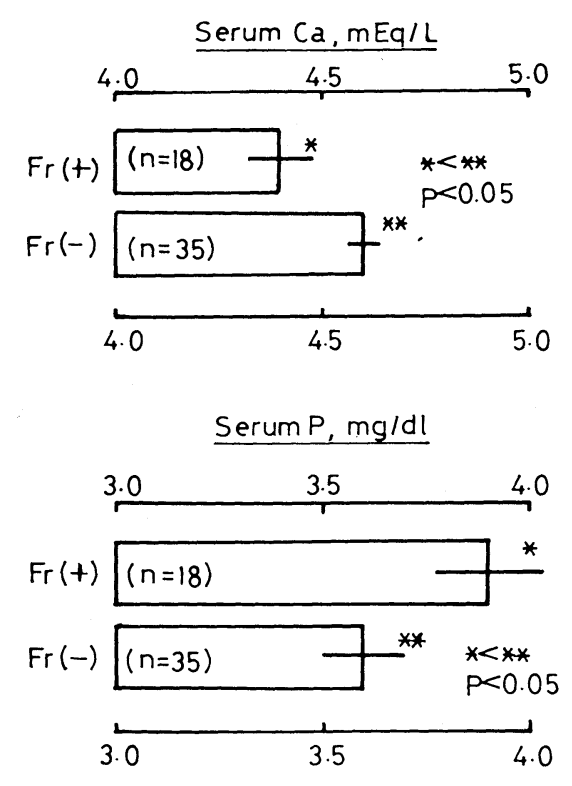

Fr: Fracture $\square$ Mea $n \pm S$. $E$.

Fig. 8. Serum $\mathrm{Ca}$ and $\mathrm{P}$ in the aged female with or without fractures. Lower serum $\mathrm{Ca}$ and higher serum $P$ in the aged females with fractures than in those without fractures.
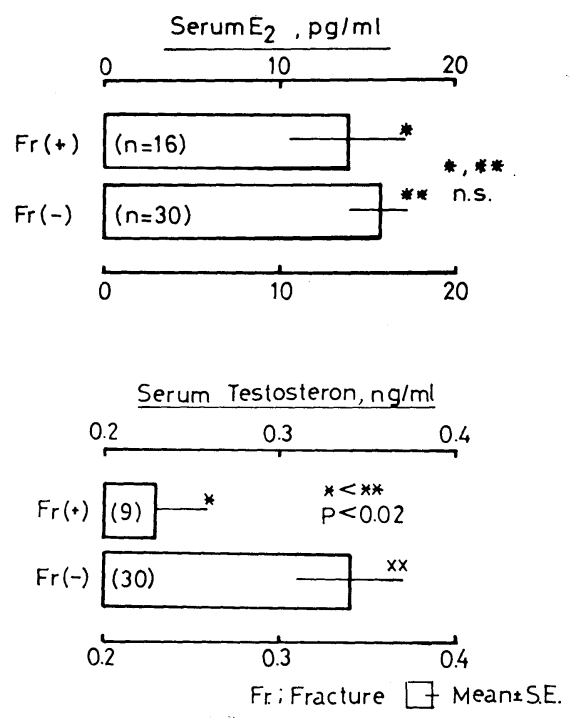

Fig. 9. Serum estradiol and testosterone levels in the aged female with or withont fractures. No difference in serum estradiol levels in the aged females with fractures and those without fractures. Lower serum testosterone levels in the aged female with fractures than in those without fractures. 
less than that of the females without fractures.

Serum Ca levels were significantly lower and serum phosphorus levels were significantly higher in the females with fractures than in the females without fractures, although they were both within the normal range. (Fig. 8) Serum estradiol levels in the aged females with fracture were not significantly different from those in the aged females without fracture, whereas serum testosterone level was significantly lower in the females with fracture than in those without fracture. (Fig. 9). Both serum $1,25(\mathrm{OH})_{2} \mathrm{D}_{3}$ levels and $25(\mathrm{OH}) \mathrm{D}_{3}$ levels were significantly lower in the females with fracture than in the females without fracture. (Fig. 10) As shown in Fig. 11, serum PTH levels were significantly higher in the females with fractures than in the females without fractures.

In view of these facts, it is possible to characterize the pathological osteoporosis in the aged females. Compared with the age matched females without fractures, those with fractures (pathological osteoporosis) are characterized by the lower levels of serum $\mathrm{Ca}$, testosterone, $25(\mathrm{OH}) \mathrm{D}_{3}$ and $1,25(\mathrm{OH})_{2} \mathrm{D}_{3}$ and higher levels of serum phosphorus and PTH.

With these information at hand, it is possible to specluate on the role of caclum regulating hormones in the pathogenesis of senile osteoporosis. Serum $\mathrm{PTH}$ is higher and serum $25(\mathrm{OH}) \mathrm{D}_{3}$ and $1,25(\mathrm{OH})_{2} \mathrm{D}_{3}$ is lower in the senile osteoporosis than in the age matched controls.

Therefore, it is possible that the loss of bone mass in senile osteoporosis is caused by the increased bone resorption due to excessive PTH and by the defective new bone formation due to inadequate amount of active vitamin D metabolites. Our hypothesis is rather contradictory to that of Riggs and Gallagher who have found a lower serum PTH levels in postmenopausal osteoporosis.

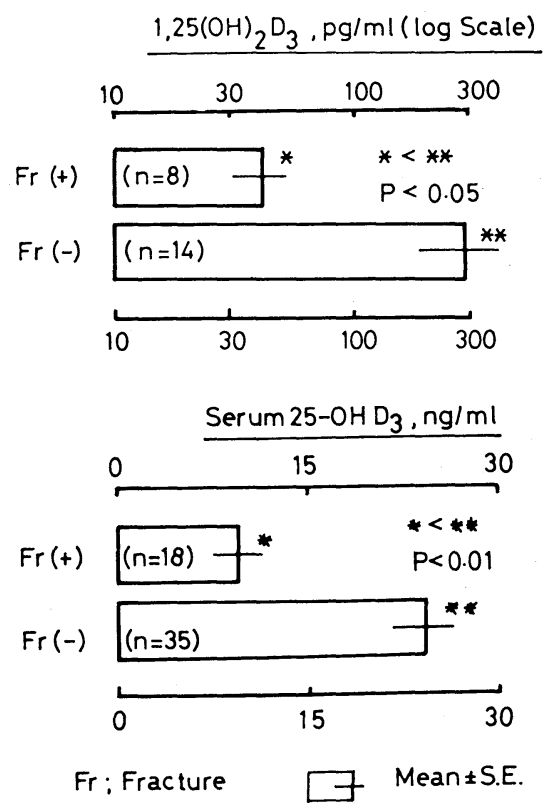

Fig. 10. Serum 1, 25(OH) $)_{2} \mathrm{D}_{3}$ and 25-OH-D $\mathrm{D}_{3}$ levels in the female with or without fractue. Lower serum $1,25(\mathrm{OH})_{2} \mathrm{D}_{3}$ and $25(\mathrm{OH})_{2} \mathrm{D}_{3}$ levels in the females with fractures than in those without fracture.

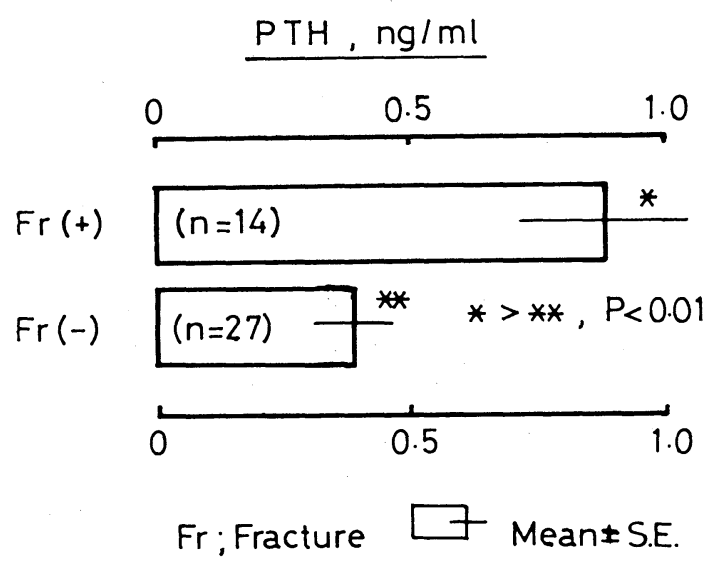

Fig. 11. Serum i PTH levels in the aged female with or without fracture. Higher serum i PTH in the aged female with fractures than in those without fractures. 
They have measured immunoreactive PTH in more than 100 patients with postmenopausal osteoporosis by using a $\mathrm{COOH}$ terminal and $\mathrm{N}$-terminal specific antisera and found normal values of $\mathrm{COOH}$-terminal PTH and normal to low values of $\mathrm{N}$ terminal PTH in these patients. However, they and Teilelbaum et al. have also recognized a subpopulation of osteoporotic subjects (15\% and $30 \%$ respectively) with elevated immunoreactive PTH values.

At present it is difficult to reconsile these discrepancies, but it may be due to the difference in the race or dietary $\mathrm{Ca}$ or protein intake.

As for the role of active vitamin D metabolite in the pathogenesis of senile osteoporosis, several possibilities are considered. Firstly, lower serum level of 25$(\mathrm{OH}) \mathrm{D}_{3}$ in senile osteoporosis may be due to the inadequate intake or insufficient gut absorption of Vit $D_{3}$. The role of sunlight exposure may be negligible, since both the patients with senile osteoporosis and the age matched controls were living in and around Tokyo where adequate sunlight exposure was available. Secondly several mechanisms could account for the decreased production of $1,25(\mathrm{OH})_{2} \mathrm{D}_{3}$ in the patients with senile osteoporosis. That a primary deficiency of renal $1 \alpha$-hydroxylase is the main abnormality seems to be quite possible since the patients with senile osteoporosis have lower levels of serum $1,25(\mathrm{OH})_{2} \mathrm{O}_{3}$ despite the high level of serum iPTH.

Higher level of serum phosphorus in the patients with senile osteoporosis may be an another possibility, since hyperphosphatemia is known to decrease $1 \alpha$-hydroxylase activity in rats.

The possibility that estrogen deficiency is involved seems to be unlikely, since serum estradiol levels in the patients with senile osteoporosis was not significantly different from those in the age matched controls. Inadequate production of $1,25(\mathrm{OH})_{2} \mathrm{D}_{3}$ in the kidney seems to be the primary defect in senile osteoporosis. This will cause an decreased intestinal absorption of $\mathrm{Ca}$ and lower serum $\mathrm{Ca}$ levels in the patients with senile osteoporosis. Lower serum Ca levels stimulates the secretion of PTH, leading to the loss of bone mass due to increased bone resorption.

Although estrogen has been shown to play an important role in the pathogenesis of postmenopausal osteoporosis, the role of estrogen deficiency in the loss of bone mass in senile osteporosis over the age of 60 may be minimum, since the serum estradiol levels in these patients were not significantly different from those in the age matched controls.

Of particular interest is our observation that serum total testosterone levels is markedly lower in the patients with senile osteoporosis than in the age matched controls.

However, the role of testosterone deficiency in the pathogenesis of senile osteoporosis in the females is obscure and require further studies for its clarification.

\section{References}

Murakami, T., et al. (1976). J. Clin. Endocrinol. Metab. 42, 88.

Haddad, J. G. and K. J. Chyu (1971). J. Clin. Endocrino. Metab. 33, 992.

Eisman, J. A., A. J. Hamstra, B. E. Kream and H.F. Deluca (1976). Arch. Biochem. Biophys. 176235.

Riggs, B. L., C. D. Arnaud, J. Goldsmith and P. J. Kelly (1973). J. Clin. Invest. 52, 81.

Teilebaum, S. L,. E. M. Rosenberg, L. A. Richarson, L.V. Avioli (176). J. Clin. Endocrinol Metab. $42,537$.

Deluca, H.F. (1976). J. Lab. Clin. Med. 87, 7.

Nordin, B. E. C., J. MacGregor and D. A. Smith (1966). Quar. J. Med. 35, 25.

Meema, H. E., M. L. Bunker and S. Meema (1965). Obstet Gynecol. 26, 333.

Davis, M. E., N. M. Strandjord, and L. H. Lanzl (1966). J. A. M. A. 196, 219.

Aitken, J. M., D. M. Hart and R. Lindsey (1973). Br. Med. J. 3, 515. 